\title{
Modern primitives leaping and stomping the earth: from ballet to bush doofs
}

\author{
Anna Haebich and Jodie Taylor
}

In the colonial history of black and white Australia, there are few recorded instances of public performances that draw together the traditions of A boriginal and settler dance cultures to create mutually constitutive corporeal dialogues. A boriginal academic Marcia Langton argues in an oft-quoted observation that settler experiences of A boriginal culture have remained over time primarily visual and distant, both spatially and culturally, rather than embodied and contingent. ${ }^{1}$ It is not surprising, then, that settler encounters with Aboriginal performance have manifested primarily in spectatorship rather than interaction. In this paper, we explore two uncommon examples of embodied performance by non-Indigenous dancers directly inspired by white imaginings of A boriginal culture. Exercising concern regarding the motivations and political implications of performance, we first examine the modernist ballet Corroboree (1954) and subsequently the neo-corroborees of contemporary 'bush doof' culture. ${ }^{2}$

The study of such hybrid performances is relatively new to Australian history so a significant 'knowable past' has been obscured from the historical agenda. ${ }^{3}$ While anthropologists studied the rich variety of traditional Aboriginal ceremony, the hybrid forms were neglected and settler Australians' enduring fascination with A boriginal performance - albeit often patronising and grounded in racism - was largely forgotten. The absence of studies of Aboriginal hybrid performances produced for the entertainment of settler audiences is now being redressed in articles and compilations. ${ }^{4}$ In 2002 , Michael Parsons published a history of the prototype public Aboriginal performances referred to generically as 'corroborees' that white audiences have avidly watched from early colonial times to the tourist productions of the present. ${ }^{5}$ Created within limits set

\footnotetext{
1. Langton 1993: 93.

2. An earlier version of Corroboree based on John A ntill's score and choreographed by Rex Reid was performed in Sydney in 1950.

3. Parsons 2002: 16.

4. Kleinert and N eal 2000; Henry et al 2000; Magowan and Neuenfeldt 2005; Kleinert, 2006.

5. Parsons 2002. 'Corroboree' is an A boriginal word appropriated from the Darug language of the Sydney region and is defined as 'a group of ceremonies, including public performances of songs and dances, covering the whole of social, economic, legal, political, religious and cultural life of the Darug people. All A boriginal clans had similar highly developed ceremonial arrangement to al low their societies to operate in a complete way.' (Van de Van 2004).
} 
by Aboriginal dispossession and pauperisation, these corroborees mixed traditional and introduced elements to meet changing white audience expectations. Anita Callaway calls such corroborees 'a fitting metaphor for the way in which Aboriginal Australians - indeed all colonised people - must constantly 'perform' for their daily survival'. 6

Less attention has been devoted to settler-created Aboriginal-inspired hybrid performances. This partly reflects their comparative rarity. Australian spectators differ from their North American counterparts who, over the centuries, dressed themselves up to 'play Indian' - from the crude dress-up of colonists who staged the Boston Tea Party to the high-culture creations of the modern dance movement, the thousands of costumed hobbyists dancing at weekend pow-wows in the 1950s and 1960s, the hippies of the following decade and finally the $\mathrm{N} \mathrm{ew}$ Age consumers of today. ${ }^{7}$ Rare Australian exceptions were daring fancy dress costumes worn at colonial balls, ${ }^{8}$ blackened film actors playing Aboriginal roles and the painted dancers of the settler-created hybrid performances that are the subject of this paper. ${ }^{9}$ While there are studies of examples of earlier creative works like Corroboree and a growing body of research on contemporary bush doof culture is emerging, the forms and the contexts of their production have not previously been brought together for comparative discussion. ${ }^{10}$

Both are the products of uneasy cultural encounters involving settler appropriation of Aboriginal cultural forms. Nicholas Thomas explains that, in the 'interplay of dispossession and repossession that defines the history of settler societies', there is an ongoing uneasy dynamic that bestows on settler acts of cultural appropriation a character of dual instability that combines in some proportion, 'taking and acknowledgement, appropriation and homage, a critique of colonial exclusions, and collusion in an imbalanced exchange'. ${ }^{11}$ As Thomas explains, this sets up a complex ambivalence that resonates through the responses and works of creative artists and others who have genuinely attempted to engage with A boriginal cultures:

Captivated by indigenous objects and performances, [they] sought to communicate their visual drama, even if they lacked understanding of their ritual significance. Encounters were marked by moments of awe, respect and partial understanding as well as misrecognition and hostility. It is this uncertain combination of acknowledgement and denial that has characterised the settler-indigenous relation in general. ${ }^{12}$

6. Callaway 2000: 117.

7. Deloria 1998.

8. Callaway 2000: 90-93.

9. The best-known example from ballet is the darkened dancer representing A boriginal

Australia in Terra A ustralis (1946). Performed by the Borovansky Ballet and based on a story by Tom Rothfield with music by Esther Rofe, the ball let represented the coming of Europeans to the continent. A less well-known example from opera is the balletic corroboree in Varney Monk's opera Collitt's Inn (Garling 1950s nd: 21, 31-32). An example of individual performance is ethnographic filmmaker Sandra Le Brun Holmes, who performed interpretations of A boriginal dance and myth for audiences at the University of Western Australia in the 1950s clad in 'black tights and a laughing female mask' (Le Brun Holmes 1999: 53).

10. See, for example, Vignando 2000: 218; Potter 2004: 1.

11. Thomas 1999: 12. 
The consequence of this process of cultural colonisation, as Andrew Lattas has argued, was that Aboriginal cultural elements were imbued with 'meanings [they] never had' and made to speak the 'cultural truths' of others. ${ }^{13}$ Added to this were the imaginings about Aboriginal culture that proliferated unchecked by genuine dialogue and that masked and perpetuated A boriginal oppression, despite the stated best intentions of the parties involved. There was also an element in these uneasy cultural encounters of what Clement Greenberg has called the 'precondition for kitsch' as artists borrowed cultural traditions for their 'own ends and discarded the rest'. ${ }^{14}$ According to Roger Scruton kitsch has been the scourge brought by modernism to 'pre-modern people': 'A century ago, no African art was kitsch. Now kitsch is on sale in every African airport.' 15

The 1954 bal let Corroboree was the product of a time when public performance and consumption of Aboriginal culture was a white-dominated enterprise, whether in performance, exhibitions, scholarly and popular publications, or films. In the context of the powerful postwar drive to create a new modern nation and to brand its distinctive qualities, A boriginal culture represented a potent 'mark of identification', symbolising Australia's unique identity, along with its distinctive landscape and flora and fauna. ${ }^{16}$ Discrete elements of Aboriginal art were commodified into a public storehouse of ideas, symbols and motifs to be exploited for hybrid works combining Aboriginal and modernist forms for use in government promotion, commercial design and the visual and performing arts. ${ }^{17}$ As A nn Maree Willis points out, A boriginal cultures became 'part of the nation's cultural capital, part of its heritage, a past living on in the present, a resource located somewhere between the nation's natural features and cultural landmarks'. ${ }^{18}$ Yet, in what we now see as an act of extraordinary cultural arrogance, A boriginal artists and custodians were left out of the loop. Ironically, the resulting new profile for Aboriginal culture suggested a 'liberal social and political climate' at the very time that governments were insisting that Aboriginal people abandon their cultural practices and assimilate into the Australian way of life ${ }^{19}$ These circumstances prompted a Melbourne book reviewer to comment at the time that, "by some strange paradox, as the A borigine becomes less a primitive man and his way of life recedes into the past, his culture becomes more and more a part of the Australian heritage'. ${ }^{20}$

Today this uncritical acceptance of modernism's creative inspiration in 'primitive' art has been replaced by critique and contention over settler appropriation of A boriginal culture ${ }^{21}$ Edward Said's influential analysis of links between imperialism and high culture contributed to the critical reassessment of modernist practice as a process of cul-

12. Thomas 1999: 11.

13. Lattas 1989: 24.

14. Greenberg 1939.

15. Scruton 1999.

16. Langton 1996: 21.

17. For contemporary comment on these hybrid artistic and commercial works, see Black 1964. For more recent analysis, see Thomas 1999.

18. Willis 1993: 110.

19. Langton 1996: 21.

20. Dugan 1968.

21. Thomas 1999: 7. 
tural colonisation; 22 but, as Maria Torgovnick explains, Western audiences are still drawn to 'the general idea of the primitive [which] becomes a place to project feelings about the present and to draw blueprints of the future' ${ }^{23}$

The West seems to need the primitive as a precondition and a supplement to its sense of self: it always creates heightened versions of the primitive as nightmare or pleasant dream. The question of whether that need must or will al ways take fearful or exploitative forms remains pressing. ${ }^{24}$

This is the case for the New Age phenomenon of individuals seeking personal meaning, spirituality and a sense of belonging in romanticised imaginings about Aboriginal culture. ${ }^{25}$ In contemporary Australian youth sub-cultural collectives, dance music enthusiasts known as 'bush doofers' have questionably proclaimed a new-found connectedness with land and culture. ${ }^{26}$ Since the early 1990s, young A ustralians have begun organising dance parties in outback and rural areas, and these events have focused significantly on achieving post-industrial, ecologically focused spirituality fostered through dance. Participants in these events are thought to be seeking what Susan Luckman refers to as:

escape ... to somewhere better, more in tune with nature and idealised, often premodern, community. Therefore an explicit connection between dancing outdoors and A ustralian indigenous and other 'traditional' communities and spiritual practices, notably Celtic and South East Asian, is a recurrent discursive trope in doof culture. ${ }^{27}$

While this claim is valid and will later be examined in regards to the highly commodified culture of the Rainbow Serpent festival, it does not wholly describe the motivations of all doof organisers and participants. During the last decade, a new breed of doof organisers and participants have begun to exhibit a serious commitment to social activism. Indigenous land rights, social justice issues and anti-mining campaigns have become the driving force behind their desire to dance and their desire to escape the homogenisation of global culture in a search for ritual and belonging, which will be discussed at length later in this article.

\section{Beth D ean's Corroboree: ballerina of the outback}

The ballet Corroboree premiered in 1954 at a Royal Gala Performance in Sydney to celebrate the visit of the newly crowned Queen Elizabeth II. ${ }^{28}$ In creating and performing Corroboree, composer John Antill, choreographer/ dancer Beth Dean and writer/ producer Victor Carell followed modernist creative practices by exploiting so-called primitive forms in their search for innovative synergies, forms and languages of moder-

22. Lattas 1989: 24.

23. Torgovnick, 1990: 244.

24. Torgovnick 1990: 245-246.

25. Terry Goldie refers to settler colonists' quest to belong and understand as 'Indigenization' (Gibbons 2002: 8).

26. For extensive discussions, see Luckman 2003; St John 2001c; Tramacchi 2000.

27. Luckman 2003: 322.

28. This section is based on published sources written by Beth Dean and Victor Carrel: see Dean 1966; Dean and Carrel 1983, 1955, 1987; and Papers of Victor Carell and Beth Dean, N ew South Wales State Library. 
nity. In this, they followed the example of artists from Picasso to Jackson Pollock who found in the primitive the languages to create their quintessentially modern works of art. $^{29}$ Antill's orchestral suite suggests the influence of Russian composer Stravinsky, notably the score for the ballet Rite of Spring (1913), inspired by Stravinsky's memories of Russian peasant life. ${ }^{30}$ Antill was also influenced by his own observations of the A boriginal 'Other' as witnessed in early tourist corroborees in Sydney and through his study of anthropological texts, including the writings of Baldwin Spencer and FJ Gillen, in creating over a 30-year period the defining composition of his musical career and of Australia's mid-20th century orchestral repertoire. Beth Dean's choreography and performance were similarly grounded in these modernist practices.

This significant hybrid creation celebrated the modern Australian nation using dance forms and mythology from Aboriginal performance combined with Western conventions to express Australia's unique identity. The ballet was conceived in the crosscurrents of awe, respect, partial understanding and misrecognition of Aboriginal culture identified by Nicholas Thomas. It was also shaped by the institutional constraints of nation, race and representation operating in Austral ia at the time, as well as the disciplinary requirements of Dean's artistic training. This made for an uneasy cultural encounter. While choreographing the ballet, Dean observed that 'steps devoid of mood, devoid of the aboriginal belief and atmosphere lose their potency and of themselves seem unusual and weird'. ${ }^{31}$ This point is central. The mix of disparate elements from distinctive aesthetic and mythological traditions produced a ballet that failed to achieve heights of creative expression in either. Its production fulfilled Greenberg's 'precondition for kitsch', and no doubt its performance evoked for some the emotional and visceral responses aroused by kitsch. How else can one explain the initial acclaim at its premiere and its subsequent rapid slide from the cultural agenda? ${ }^{32}$

A merican-born Dean and her Italo-A ustralian husband, Carell, ${ }^{33}$ were inspired to leave New York in the late 1940s to study A boriginal dance in Australia by anthropologist Charles Mountford's vision of the:

centre of a continent where, surrounded by empty silence, an old man, with bearded face and jutting eyebrows, sat chanting. The shadows about him were

29. Rubin 1984.

30. Berg 1988.

31. Dean and Carell 1955: 209.

32. Dean's Corroboree was performed in 1970 for the Captain Cook Bicentenary with African American dancer Ronne Arnold as principal dancer. Dean lobbied unsuccessfully for it to be added to the national bal let's repertoire and to be included in Australia's 1988 Bicentenary cel ebrations. In 1994, a notated record of the ballet was prepared, and the following year Stanton Welch created a third version of Corroboree to cel ebrate the 50th anniversary of the United Nations charter using contemporary dance forms to express a 'general ised ritual' (Potter 2004).

33. Beth Dean was born in 1918 in Denver, Colorado. She studied ballet there and in Paris, and performed in Europe and the United States. In the early 1940s, Dean worked in Hollywood where she met her future husband while performing as prima ballerina in the film The W altz King, the story of the life of Johan Strauss (Dean and Carell 1983: 2). Victor Carell was born in Australia to an Italian migrant family. He trained as an opera singer in Sydney, London, Chicago and in Canada (Dean and Carell 1983: 2). 
peopled with leaping, virile young men, their dark glistening bodies ochre daubed and decorated in fantastic designs of feather down. ${ }^{34}$

Dean's fascination for A boriginal dance also derived from her interest in A merican modern dance which, despite her training in classical ballet, provided the inspiration for her life's work. The influence of dance pioneers Ruth St Denis, Ted Shawn and Martha Graham permeated Dean's creative work and writings. For them, primitive dance expression and movements, themes, rhythm, instruments and dance steps held powerful synergies with the potential to create profound experiences for performers and audiences. Jaded with the formalism of classical ballet, they created new modern dance languages and idioms from primitive, ethnic and folk forms. ${ }^{35}$ From these elements, they shaped composite dance dramas with sets and costumes designed by contemporary artists and musical scores written by leading modern composers. Martha Graham also sought profound transformative encounters that would energise repressed emotions and surrender to what Marina Torgovnick calls the oceanic dimensions of human experience. ${ }^{36}$ To this end she undertook first-hand study of indigenous dance and attended religious ceremonies and shamanic rituals in the American Southwest. ${ }^{37}$ When Ted Shawn toured in Australia in 1947, he explained his quest to view Aboriginal dancers as follows:

Theatrical dancing is liable to become anaemic and to begin to die of dry rot unless now and then, the dancer can sink his roots down into primitive dance ... [The primitive dancer] dances because dancing is, to him, a magic formula. It is to him the finest expression of his religious consciousness. ${ }^{38}$

Shawn described the performances he saw in the N orthern Territory as being 'so outstanding that I was knocked off my feet' and singled out for particular praise the legendary Wagaitj dancer Mosec Manpurr whom he claimed would be 'a sensation in London or New York'. 39

The modern dance movement brought a new respect and willingness to add selected primitive sacred dances to the canons of classical dance in recognition of their 'great age, exactness of preservation, economy of movement, special ised technique and symbolic stylisation'..$^{40}$ There was al so a new impetus to salvage, preserveand resurrect lost or disappearing styles, techniques and forms. This brought the movement into contact with anthropologists and their fieldwork methods of studying dance and their fixation on salvaging dying cultural practices. ${ }^{41}$ These were positive steps, but in retrospect it is obvious that the connections between the modern and the primitive were intrinsically unequal and inevitably exploitative. The dancers' modernist reworkings and transformations reflected their own artistic, commercial and political interests. In

34. Dean and Carell 1955: 2.

35. Dean 1966: 101.

36. Torgovnick 1996: 8.

37. Berg 1988: 142.

38. Australian N ews and Information Bureau 1947: 70.

39. Mosec was living at the Delissaville Settlement (now Belyuen) on the Cox Peninsula west of Darwin when Shawn saw him dancing. Mosec died in 1950.

40. Dean 1966: 64.

41. Dean 1966: 157. 
the creative process, the original meanings, purposes and histories of the appropriated primitivist elements, the identities and lives of their original creators, and the cultural conventions that guided their practice were overlooked and forgotten..$^{42}$ The style and forms of what Michael North calls the resulting 'modern-created-primitive-dialects'were the property of alien artists, anthropologists, critics and audiences, who shaped public imaginings and expectations of the primitive and of the authenticity of works by primitive artists seeking to establish their own creative identities. ${ }^{43}$

Dean's respect for A boriginal dance is expressed in her book The many worlds of dance, where she writes that 'the poetic language of hours of chanting, the décor, and Iong disciplined ritual, the performance as total, or lyric theatre, is indeed classic' ${ }^{44}$ In her quest to understand primitive dance, Dean studied anthropological texts and during her concert tour of $\mathrm{New}$ Zeal and was instructed in traditional dance by Maori women. This embodied experience of learning together with the paucity of available anthropological studies of A boriginal dance must have influenced her determination to observe authentic Aboriginal performances first-hand in remote Australia. In 1952, Dean argued the need for this study in a letter to Sir Paul Hasluck, the federal minister responsible for A boriginal affairs. She stated that:

Since Dance is intimately bound up with the whole psychology of Aboriginal social, economic and religious life - I believe that its study has a value far beyond even its high artistic merits. A mong primitive groups one sees the true soul of a people through their deepest thoughts hopes and desires often expressed as Dance Drama. It seems that this is particularly true of the Australian Aborigines. ${ }^{45}$

Dean's invitation from Dorothy Helmrich of the Arts Council of Australia in 1953 to choreograph Corroboree was the catalyst for Dean and Carell to set off on an eightmonth, 10,000 mile trip through Northern and Central Australia to observe, record and film A boriginal dance and ceremonies. In doing so, they stepped out of the artistic comfort zone where primitive art could be encountered visually and from a distance through texts and artefacts. Their journey was ambitious in time spent and distance travelled, as well as the range of meetings with A boriginal people and of performances observed. In the segregated world of 1950s outback Australia, the couple experienced the usual barriers to interaction with A boriginal people - language, culture, race and social pressures to mix with white residents and conform to their ways. However, their interest in dance led to invitations from A boriginal groups to travel with them into the desert to attend initiation ceremonies.

Dean and Carell recorded their journey in the book D ust for dancers, published two years after the trip. The account is a case study in the discourse of cultural extinction, which permeates the book despite the couple's own eyewitness accounts of vital per-

42. This argument follows critiques of modernist artists' exploitation of primitivism following the 1984 exhibition at the Museum of Modern Arts, Primitivism in 20th century art: affinity of the tribal and the modern. See McEvilley 1996; Clifford 2003.

43. North 1994.

44. Dean 1966: 64.

45. N ote on letter between Dean and Carl Strehlow, 24 September 1952, Papers of Victor Carell and Beth Dean, New South Wales State Library. 
formances by strong community groups. Influenced by anthropology's paradigms of cultural rescue and salvage, they wrote that:

most experts agree that the Australian A borigines are no longer a dying race, for their numbers are increasing. But their culture - their age old beliefs and customs - their dances as part of a living, vital link with their religion, history and country - their totemic stories - their unique drawings and the spirit behind them - all these are dying. ${ }^{46}$

The mechanisms of cultural extinction were the demoralising effects of 'civilisation' on Aboriginal people and the tensions generated when assimilation trapped 'Stone Age man' between two worlds. Then there was the perceived cultural breakdown when, as 'young A boriginal men come more and more into our "white fellow" ways, they are spending less and less time with the old men of the tribelearning the traditional dances songs and stories that have been handed down through untold generations as the tribes wandered their long walkabouts over Australia'. ${ }^{47}$ At one point in the book, the couple argues that total Aboriginal segregation is the only solution. Yet this contradicts their endorsement elsewhere of the assimilation of Aboriginal people into modern Australian life. Paramount for Dean and Carell was their perceived duty as artists to 'rescue A boriginal culture from entire oblivion'. ${ }^{48}$ Their clearly stated intention was to promote public respect for the theatre and virtuosity of Aboriginal performance with its creative use of staging, props, lighting, music, dance, body adornment, the compelling atmosphere of dust, smoke and fires and enthusiastic audience participation. They were united in their intention to, as Dean put it, 'call out to a blind and thoughtless world that these Aboriginal dancers and musicians are truly great artists'. 49

The couple had the opportunity to observe many of the forms of traditional Aboriginal dance in the Northern Territory. At Manbulloo Station near Katherine, 'house girls' performed djarada ('women's business' dances) and the young dancer and didgeridoo player Gilligan from the same Wagaitj tribe as Mosec thrilled them with his virtuosic performances of the short theatrical wongga dance style. They observed that his brilliance marked him as 'a great artist among his people ... he was a young god ... he held us spellbound'. ${ }^{50}$ From there the couple travelled east into Arnhem Land to Beswick Compound - now Beswick (Wugularr) Community - where they watched a series of 'play about dances' and performances for the Warrangan ceremony. This impressed on them the power of the men's

violent stamping, digging deep and hard into the earth, making it fly up about them, so that they are right in the centre of an eddying dust cloud. They do this because they believe that they are gathering strength from the earth; they feel a joy springing right up from the soil, through their pounding legs into their bodies. And they dance about everything in their life, for, to them. To dance is a joy and a duty. It gives them a sense of fulfilment. ${ }^{51}$

\footnotetext{
46. Dean and Carell 1955: ix.

47. Dean and Carell 1955: ix.

48. Dean and Carell 1955: ix.

49. Dean and Carell 1955: 210.

50. Dean and Carell 1955: 26.

51. Dean and Carell 1955: 41.
} 
They then travelled further into Arnhem Land to Mainoru homestead, where Remberanga people performed 'highly exciting' warma dances for them 'that tremble the knees or dip and rise like Russian Cossacks'. ${ }^{52}$ In Darwin, they saw Tiwi dancers from Bathurst and Melville Islands perform over 16 different dances in an afternoon, culminating in part of the Pukamuni Burial Ceremony. The couple then drove out to the Daly River where they camped near the police station and observed large gatherings performing ritual dances for a young girl's initiation.

From Alice Springs, they travelled to Yuendumu settlement where they recorded sacred men's and women's dances and noted the strict separation of their performances. Here they met Djungartu (N osepeg), a Pintubi man who invited them to go bush to observe the preparations and performances of dance and chanting for one stage of a boy's initiation ceremony that went on each night over a couple of weeks. For Dean and Carell, this proved a dramatic experience with extremes of noise and excitement, women's wailing, daily preparation for dancing, separation of men and women and then gatherings for communal performances. The description of a particular climactic moment in the cycle of the ceremony stands in contrast to the more factual tone of the book, and no doubt influenced the couple's reinterpretation of the seven stages of Corroboree as a ritual of initiation:

The chanting and dancing went on for a long time, till suddenly, the men madea fierce concerted rush towards the women, screaming at them and threatening them in rough, hoarse tones. For a moment, an atmosphere of all-hell-let-loose prevailed ... It was so savage ... so complete ... so sudden ... In the dark the women were all running madly back toward the camp ... As they ran, the aboriginal women were screaming and calling out, some of their cries having an edge of real panic. As the women dashed past her, Beth felt a spasm of fear at her heels, and went with them .... A bout her the women were all screaming with an incredible volume of sound. ${ }^{53}$

The remainder of the trip seemed anti-climactic as they travelled to Ayers Rock then to Ernabella and on to A delaide, where they met up with 'Monty' (Charles Mountford) at the South Australian Museum. They then returned home to Sydney where they threw themselves immediately into the task of creating the ballet within a period of a few weeks.

Corroboree was the first of several major artistic collaborations between Antill, Dean and Carell. They were united in their intention to 'pay tribute through contemporary music and dance ... to the great poetry, discipline and the very spirit of [Aborigines'] many faceted arts'. ${ }^{54}$ Despite their direct experiences of Aboriginal performance, they saw no dilemma in appropriating A boriginal dance forms to achieve this goal.

Dean decided to take the lead role of the male initiate in contradiction to the many examples she had observed of the strict gender divisions and prohibitions that characterised A boriginal performance. This decision was crucial in transforming the narrative

52. Dean and Carell 1955: 64.

53. Dean and Carell 1955: 173.

54. Dean to Director of the Australian Ballet 9 A pril 1979, Papers of Victor Carell and Beth Dean, New South Wales State Library. 
of a primitive Aboriginal male ceremony into a civilised, feminised performance suitable for the young Queen Elizabeth and cultured Sydney audiences. At the same time, as Catrina Vignando points out, by including other women dancers Dean was challenging public assumptions that denied the role of women in A boriginal sacred life and ceremony. ${ }^{55}$ Conditions of production inevitably continued the creation of a Westernised dance performance for a civilised space and audience. The team had to work within the constraints of the orchestral score, staging requirements, skills of the dancers, audience expectations and their own artistic expectations. There were al so the considerations of royal convention, one being that the Royal Gala was a variety performance so that it was not possible to perform the ballet in its entirety.

Carell adapted the stages of an A boriginal boy's initiation to the seven sections of the Corroboree orchestral suite to create a modernist narrative expressing the universality of the human condition "based on the age-old theme of initiation, which is discipline learned through trial by ordeal'. Dean later wrote that while she drew on Aboriginal movement and steps she was not recreating a corroboree but a 'contemporary ballet set to sophisticated symphonic music' ${ }^{56}$ Male and female dancers were selected for their familiarity with classical and modern dance movements and their willingness to work with Dean to extend to Australia the "style called "modern" or "contemporary dance" ... [and to create] true theatre - a translation in dancelanguage from one culture to another'. ${ }^{57}$ Dean conducted classes for all dancers in A boriginal dance movements and perspectives in order to:

instil the depth and potent emotional beauty of aboriginal dance into people who had never seen an aborigine; to try to enthuse their will to picture in the mirror of their minds the excitement of an aboriginal ceremony which they had never known even existed. They had, we believed, to learn to feel the dance quality as we had felt it, and by doing so, to infect each audience with the beauty and thrill of this pristine ideal of the aboriginal mind - to carry the continuous line direct from the aborigines in Central A ustralia to a city audience in Sydney. ${ }^{58}$

No Aboriginal dancers were included in the performance. Instead the all-white cast had their skin blackened and wore dark woollen body tights. Body markings were depicted by chenille and fur trims.

Dean later wrote that she worked on the choreography 'in days and weeks alone with the music'. ${ }^{59}$ Technically and conceptually, the forms were contrastive - even the male virtuosic performances. Djon Mundine writes that most A boriginal dance is very grounded and low to the earth:

'Foot to the earth' as the famous A boriginal choreographer Stephen Page described it. It's about physical memory - to be able to tell the story by putting yourself into the movement. Women move in a kind of minimalist shuffle (not really a step) with the feet always in thesand; a quiver of the thighs - a skip perhaps ... A type of

\footnotetext{
55. Vignando 2000: 219.

56. Dean 1966: 11-12.

57. Dean and Carell 1983: 146.

58. Dean and Carell 1955: 169.

59. Dean 1966: 11-12.
} 
'dance fractal' ... interestingly the performer may actually spend a longer time painting up than actually dancing. ${ }^{60}$

The assumption that Dean and her dancers could readily make the transition from the practices of classical ballet inscribed in their bodies to the complexities of A boriginal performance suggests the sense of cultural superiority operating even in the sympathetic approach of Beth Dean to her subject.

Today a production that so clearly breached A boriginal cultural protocols and rules regarding cultural appropriation would never be presented in an Australian theatre. Yet in 1954 audiences steeped in imaginings and preconceptions about Aboriginal culture and the primitive deemed the ballet world class and the highlight of the Royal Gala performance. Critics lauded Dean's success in creating from the 'elementally Australian [a ballet that] ... transcends mere local interest and belongs to the world'. ${ }^{61}$ Others lauded the achievement of 'an American who shows, as even our best writers have not been able to do, what is basically Australian' ${ }^{62}$ One critic wrote that Dean had 'crept inside the skin of our aborigines: she knows his mind, his spirit, his beliefs, his customs and his art of dancing', suggesting a new perceived authority for the creative artist to bestow authenticity on works based on Aboriginal culture. ${ }^{63}$ Dean has always maintained that her intention was to encourage respect for Aboriginal performance by creating a 'proudly dignified yet severely humble offering of the fruits of years of earnest endeavour to understand the activating spirit of aboriginal lore and to translate it into live theatre for all to share' ${ }^{64}$ Ironically, the effect of her good

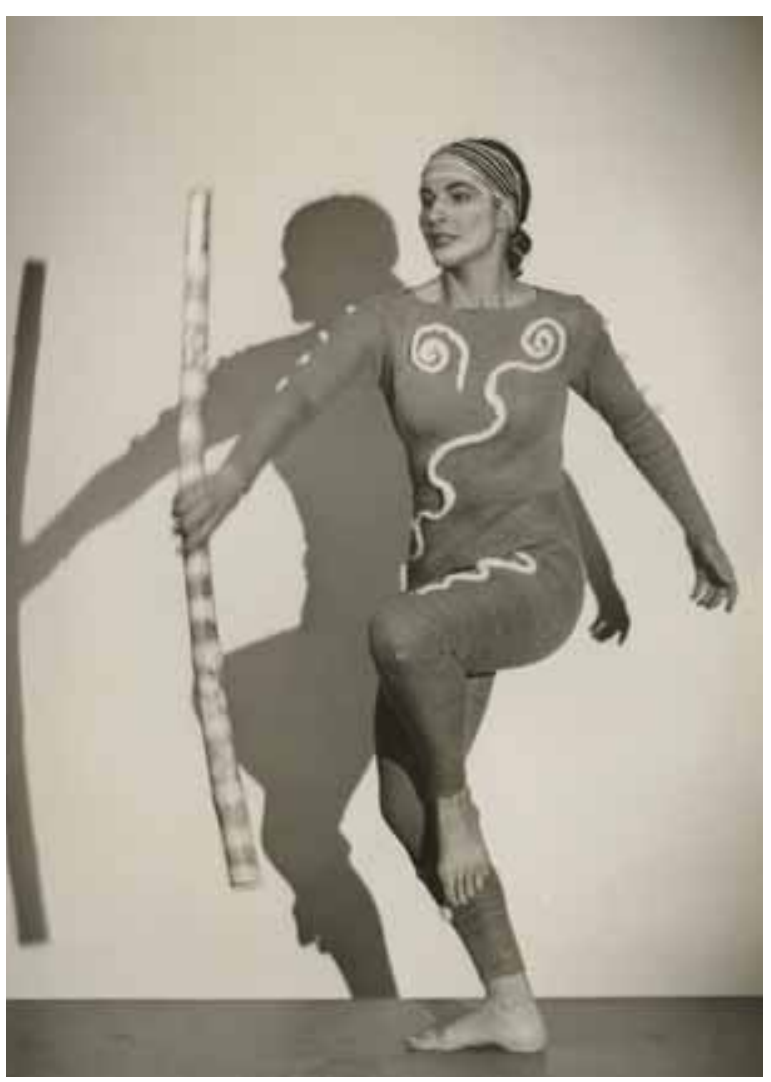

Fig 1. Beth Dean in Corroboree. Royce Rees collection of Sydney theatre photonegatives, 1946-1967, PXA 739, Mitchell Library.

60. Mundine 2003: 68.

61. Sunday Telegraph, newspaper reviews, typescript, February 1954, Papers of Victor Carell and Beth Dean, N ew South Wales State Library.

62. Editorial, D aily Examiner, typescript, February 1954, Papers of Victor Carell and Beth Dean, New South Wales State Library.

63. Columnist Eunice Gardner; M irror, newspaper reviews, typescript, February 1954, Papers of Victor Carell and Beth Dean, N ew South Wales State Library.

64. Dean and Carell 1955: 211. 
intentions was to strengthen official resolve to assimilate A boriginal people. The appropriation of A boriginal forms to represent the modern condition and nationhood and the all-white performance reinforced the impression that Aboriginal culture was indeed dying, and that assimilation was the only way forward. As such, Dean's creative work was firmly embedded in ongoing colonial relations of domination and power.

For the new wave of A boriginal performers seeking public recognition from the 1960s, these hybrid creations proved to be major obstacles. They had to battle widespread acceptance of cultural appropriation without acknowledgment or compensation to traditional custodians and performers, and their fragmented, misinterpreted and misrepresented versions of A boriginal culture. A boriginal performers had to compete with non-A boriginal artists like Dean, A ntill and Carell, who continued to receive commissions to create Aboriginal-derived performances into the early 1970s. They also had to prove to white audiences their ability and authority to perform and the authenticity of their work in the face of modernist interpretations that branded them as Stone Age and exotic. On their side was the vitality of their performances compared with these hybrid creations. The new political contexts of A boriginal protest and campaigns for social justice and land rights also demanded a move away from exploitative practices and required the creation of a new Aboriginal imagery in the public sphere. This found expression in the surge of A boriginal artists, performers and writers in the national and international arenas from the 1970s to the present. A boriginal artists al so began to lobby politically and through the courts for copyright protection for their works and formal acknowledgment of the special features of A boriginal cultural rights and obligations and their connections with country, spirit and well-being.

We now turn our attention to a seemingly disparate form of modern dance emerging almost half a century after Dean's balletic attempt at dancing a white corroboree. Bush doofs - a derivative of rave culture - share little commonality with ballet, aside from the obvious physical expression of dance. The bush doof is an autonomous communal event; dancers who gather at a bush doof are generally not professional dancers, but rather people who congregate in a designated location for the purpose of socialising, self-expression, personal enjoyment and communal connectivity which they achieve through music and dance. The following investigation will briefly outline the general ethos of bush doofing in Australia and address the bush-doof phenomenon in the context of the uniquely Australian FreeNRG culture, focusing specifically on its commitment to Aboriginal causes and its attempts at creating intercultural alignments between black and white Australians via outback dance parties. It will make special reference to the bush doof event known as Earthdream and the Rainbow Serpent Festival in an attempt to locate genuine examples of FreeNRG cultural participation, which is situated in contrast to commodified cultural experiences.

\section{Bush doofs, neo-corroborees and postcolonial dance activism}

I think there's a sense of the spirit of the land. This land we now call Australia has a real spirit to being stomped. And if you've ever watched Aboriginal dance, it's very much about stomping the earth ... if you watch techno ... it's very much about stomping the earth ... [it] brings energy into the body, Earth energy into the body. ${ }^{65}$ 
Like the Western dance traditions of classical and modern ballet, rave culture is largely a European and North American import. Our contemporary understanding of the term 'rave' is located within the 1960s psychedelic hippie culture, but more recently has become synonymous with urban youth subculture, large-scale dance parties, electronic dance music and illicit drug use. While this remains indicative of mainstream raving practices, we find evidence of a counter-cultural phenomenon dwelling in the fringes of the Australian rave scene. Graham St John, a leading A ustralian cultural studies scholar on this topic, refers to this evolving post-rave scene as the FreeNRG movement. FreeNRG is radically postmodern and extremely neologistic, conjuring up rich imaginings of futuristic dance spaces in juxtaposition with the Australian outback by employing colourful language such as 'eco-rapture', 'technotribalism', 'future-primitives', 'neo-corroboree' and 'psycorroboree' to describe a post-rave dance experience that promotes awareness of social justice issues facing Indigenous Australians. In the forward to St John's book, FreeN R G : notes from the edge of the dance floor, Ken Gelder suggests that post-rave FreeN RG culture has invoked an 'A boriginal aura', arguing that:

FreeNRG stands at the front line of reconciliation, making contact and forging intercultural alignments and affiliations: working always in sympathy, even empathy, with A boriginal and ecological paradigms ... FreeNRG is all about the ritualistic production of an ethically correct sense of settler occupation of this country. ${ }^{66}$

In this context, the term 'FreeN RG' is drawn from the title of St John's book and is not a solidified cultural movement as such. However, it is an idea and an ethos underpinning some of the post-rave dance parties that occur in the Australian outback and will be used throughout this discussion to represent moments of post-rave culture that attempt to forge intercultural affiliations between Indigenous and non-Indigenous Australians. For FreeNRG culture to be seen as a successful advocate for social change, it must not simply - as A ntill, Dean and Carell attempted - pay tribute to A boriginal culture through contemporary music and dance or save what they paternalistically saw as a 'dying culture'. Rather, it must attempt to create a new dialogue - one that is mindful of the oppression perpetuated by those like Antill, Dean and Carell, who in the past danced with the best intentions but failed to acknowledge their assimilatory methods and colonial discourse. Turning now to the bush doof scene from which FreeNRG culture has emerged, we begin to see a new generation of white Australians leaving the urban landscapes and entering the Australian outback in a way not dissimilar to that of Dean and Carell 50 years earlier.

Dance parties and collective gatherings associated with rave culture were once contained within metropolitan areas. In many instances, the location of a rave will be regulated and legally scheduled while at other times they involve the hijacking of urban spaces in an attempt to create 'temporary autonomous zones' in which dancing becomes a performance of oppositional politics. ${ }^{67}$ While the majority of dance parties across the country are still city-bound, there is a growing feeling among Australian post-ravers that urban rave culture has become tainted by commercialism and middle- 
class consumption. Those who seek a more spiritual experience are now promoting and participating in psychedelic dance parties in the Australian bush known colloquially as the bush doof.

The bush doof is a unique product of post-rave culture and is particularly suited to the expansive A ustralian landscape. The term itself is an onomatopoeic suggestion of sonically reinforced drum and bass music echoing through the Australian bush. The remote location of the bush doof provides a space free from noise regulations, city pollution and urbanised architecture. These locations are preferred by participants for the additional stimulation provided by nature, such as the rising and setting sun, a more visibly pronounced lunar course, and the superior clarity of evening stars, which many metropolitan dwellers rarely experience without a looming industrial backdrop. Des Tramacchi advocates that ecological surroundings 'link the doof community to the landscape and allows the occurrence of spontaneous mystical bonds with nature'. ${ }^{68}$ The cathartic and radical ideology of the bush doof corresponds with Hakim Bey's original notion of temporary autonomous zones in which doofers seek an alternative form of community. ${ }^{69}$ In contrast to many of the metropolitan raves and dance parties, the doof is conceived as a greater spiritual, and almost sacred, experience. Doofers seek a tribal encounter and boast a communal enlightenment, which often extends beyond the use of illicit drugs prevalent within urbanised raver practices. ${ }^{70}$ In fact, the official Earthdream website for 2006 suggests to participants that 'if you choose to be off your face you may well miss the point, surely it has reached the time to evolve past these induced states? Be clear and clean enough to induce your own natural blisses. ${ }^{.71}$ While the use of these substances and other chemical psychedelics is by no means absent from bush doofs, it is suggested that they are secondary to the connectedness and communal enlightenment achieved by eco-rapture - that is, the feeling one gets from dancing and stomping upon the earth.

Traditionally, doofers congregate to dance. Their style is not choreographed, but rather a free form of dance, an impulsive reaction to the pounding repetitive beats of electronic musical accompaniment. Bush doof participant Kathleen Williamson notes that 'when dance, vibration and movement are introduced, we are suddenly communicating with ourselves in very challenging ways, as well as with an infinite myriad of other energies, entities, ideas and emotions'. ${ }^{72}$ Here, Williamson emphasises the importance of dance to the doof experience, highlighting its ability to communicate and channel energy and emotion from within the self and between others. The spiritual capacity of the dance seems to be a concurrent thread attracting and connecting doofers across the country; but dance serves multiple purposes spanning the pleasurable, spiritual and political. Doofs are often imagined as inter-tribal collaborations, usually

68. Tramacchi 2000: 208.

69. Bey 1991.

70. Drugs commonly used by ravers indude the psychoactive drug known commonly as ecstasy (MDMA) and the stimulant known as speed (amphetamine). These drugs are consumed to heighten one's enjoyment and provide the consumer with an artificial increase in energy levels to assist with dancing for extended periods of time.

71. The Official Earthdream H omepage, http:/ / www.angelfire.com/ mt/ earthdream2000/ itinerary (accessed 24/3/2006).

72. Williamson 1999. 
organised by various technotribes from around A ustralia. In this instance, the doof is sometimes referred to as a corroboree:

Consistent with 'neotribalism', technotribes are interconnected in a network each node representing a possible site of belonging for contemporary nomads, achieving their fullest (sometimes only) expression in the party, the festival, the TAZ [Temporary Autonomous Zone], the direct action, the doof, or, as it is often designated, the 'corroboree'. ${ }^{73}$

Evocatively naming themselves in a fashion that indicated technological and primitive hybridity, certain technotribes such as Vibe Tribe, Ohms Not Bombs and Labrats have been gathering annually since 1999 in merriment, in protest and to experience a new age tribal spirituality at a global neo-corroboreecalled Earthdream:

Transpiring over several days and nights, participants at 'techno-corroborees' ... are more inhabitants than 'punters' ... The new 'corroborees' are sites where ultimate concerns are celebrated, dramatised or demonstrated. ${ }^{74}$

Many of these collectives have been taking their unique form of doof protesting around the country since the late 1990s, and during that time Aboriginal and non-A boriginal dancers have united to dance on the land and celebrate difference while raising awareness of, and attempting to combat, social, ecological and political issues such as the mining of uranium on Aboriginal land, the teenage petrol-sniffing epidemic and repressive colonial governance. ${ }^{75}$ Doof participant and author Peter Strong recalls a moment from Vibe Tribe's voyage in 1996 when they set out through central Australia making their way to Darwin:

We approached the Bagot A boriginal settlement about doing an interactive event there. When we got there to set up, the elder who had said 'yeah, bring your disco here', had gone home to fish and no one knew anything about it. Anyway, we put the word out and as we arrived and were unloading the system from the trailer, a mob of kids came to assist us to put up the décor. They were laughing and interested in every aspect of the equipment as the first track [song] was dropped [played]. Projections shone and A boriginal and non-A boriginal danced for hours until midnight. ${ }^{76}$

In 1998, Ohms Not Bombs began a desert tour in protest of the Jabiluka mines, hosting multiple doofs in Uluru-Kata Tjuta National Park and Darwin. The following year Ohms Not Bombs became involved in numerous protest parties in a range of locations such as Lake Eyre in northern South Australia and Wooyong in northern N ew South Wales. During the parties at Lake Eyre and Roxby Downs, technotribal activists forged a connection with A rabunna elder Kevin Buzzacott. Kevin was battling against the Roxby Downs uranium mine which was threatening both the ecosystem and A rbunna culture. ${ }^{77}$ Doof participant in Earthdream 1999, Rufus, recalls his experience with Kevin:

\footnotetext{
73. St John 2001a: 21.

74. St John 2001a: 25.

75. St John 2005b: 14-16.

76. Strong 2001: 81-82.

77. Strong 2001: 87.
} 
Every day we would sit around the fire and Uncle Kev would describe his vision of the future, or what he thinks are the steps we need to take to create the future that we want to live in. His ideas were progressive in the sense that anyone who comes out here to this bit of land and feels the spirit of the old lake and dances on the land, they're welcome. And you feel the call to defend it. And that's what Uncle Kev's all about. Hekeeps on talking about finding a way home, or finding a way forward, and his idea is that we have to do it together. A boriginal culture and white culture. We sort of have to work together in spite of all our historical conflicts. 78

Earthdream is potentially the most significant FreeNRG doof, encapsulating a sincere sense of dance activism and social protest. Earthdream was the brainchild of the Mutoid Waste Company based in London (1988), but this powerful form of hegemonic resistance soon travelled around the world, forming in other countries and taking up cultural and ecological issues of colonised societies. According to the Australian website of Earthdream 2006, the organisers 'are attempting to find a balance between full on rave, workshops addressing land rights, water and uranium issues, and finally corroboree sharing with local Aboriginal groups'. ${ }^{79}$ Organisers of and participants in Earthdream gatherings insist that they are directly 'responding to requests from various Aboriginal communities (including the Mirra, Adnyamathanya and Arabunna) who are seeking support for their campaigns to defend country, particularly in opposition to uranium miners'. 80

Earthdream is a highly successful doof that has a history of working in solidarity with local A boriginal communities, suggesting that it actively seeks a genuine intercultural dialogue between Aboriginal and non-Aboriginal Australians. It provides Aboriginal and non-Aboriginal participants with a common project and, through the execution of this project and by dancing and performing together, it fosters acceptance and encourages cultural sharing. Moreover, it is a means for urban dwellers to get closer to country and, in doing so, enrich their knowledge and gain new perspectives on landscape. A ccording to St John, 'dancing is an embodied participation in landscape, an intentional means of connecting with place'. ${ }^{81}$ Since 1999, Earthdream participants have returned annually to the southern point of Lake Eyre to reconnect with the spirit of the land and its people. In all documented instances, Earthdream organisers have legitimately gained the permission of traditional land owners to host their events and in one notable instance 200 Kooris participated in what was described as a 'non-violent dance-scape ... proving again that dancing can free your mind'. ${ }^{82}$ On the dusty dance grounds of this site, Earthdreamers have sought an embodied participation in reconciliation and the ethos of FreeNRG culture (as previously suggested by Gelder) is activated via dance.

Earthdream is not the only large-scale bush doof in the country; in fact, numerous other events take place in rural locations which similarly attract dance enthusiasts to

\footnotetext{
78. Rufus quoted in St John 2001b: 121.

79. The Official Earthdream H omepage, http:/ / www.angelfire.com/ mt/ earthdream2000/ (accessed 24/ 3/ 2006).

80. St John 2005a: 322.

81. St John 2005a: 331.

82. Karl Fitzgerald quoted in St John 2001: 26.
} 
congregate and stomp upon the earth. But do all bush doof events claim to engage in a legitimate form of ethically correct dance activism, inspiring engagement with A boriginal culture? Or are some bush doofs guilty of inadvertently perpetuating A boriginal oppression via the commodification and consumption of A boriginal culture? To answer this question, another event called the Rainbow Serpent Festival is briefly addressed.

The growing popularity of the doof experience has encouraged a sort of metropolitan cultural diaspora, scattering sound systems, pyrotechnics, laser light displays and swarms of disheartened post-ravers across the country. Many of these people are searching for a momentary experience of 'Otherness' via far-fetched imaginings of A boriginal culture and (to recapitulate on Luckman's earlier suggestion) an escape to a romanticised premodern community. The bush doof known as the Rainbow Serpent Festival has been running annually since 1997 outside the township of Beaufort, western Victoria. The Rainbow Serpent Festival is organised by Green Ant Productions, a 'collective tribe ... [of self proclaimed] technoshamanistic DJ's, musicians, artists, producers and promoters each with a vision of how to create spiritually empowering rituals that awaken the spirit, mind and body'. ${ }^{83}$ Via literal references to the Dreaming spirits, Rainbow Serpent and the Great Green Ant, and through appropriation of Indigenous iconography in many of its poster designs, this festival exploitatively embeds its public image with A boriginal signifiers in an attempt to create an exotic and primitivist facade ${ }^{84}$ According to festival organisers (who boldly suggest this without any supporting evidence of Aboriginal consultation or citation):

While dancing their Dreamings, aborigines spiritually connect themselves to the land and to the Dreamtime. The drumming of feet during the dance draws the earth into dialogue with the dancers, allowing the ceremony to bring the power of the Dreaming to life. ${ }^{85}$

The Rainbow Serpent Festival is held annually on the Australia Day weekend in January, which in itself suggests a lack of empathy towards A boriginal consciousness. A festival is typically a celebratory cultural gathering, thus by staging a festival on (or as close as possible to) the day which nationally commemorates the arrival of the First Fleet in Sydney Cove, the Rainbow Serpent Festival is inadvertently celebrating the devastating effects this historic event had on A boriginal culture. Celebrating on this day seems incongruous with the ethos of harmony, healing, spirituality and connectivity expressed by Green Ant Productions. Moreover, the available archive of Rainbow Serpent Festival flyers and web text consistently refers to this day as 'A ustralia Day' without acknowledging the significance of the invasion, or the fight for survival that is also marked by this day. While it is clearly not the intention of festival organisers to be blatantly distasteful in their promotional text, advertisements or scheduling, this festival presents yet another example of the paradox of white Australia's consumption and imaginings of A boriginal culture.

83. The Official Green Ant H omepage, 'Background', http:/ / www.greenant.com/ index1.htm (accessed 22/ 6/ 2007).

84. See example of appropriated iconography in the Rainbow Serpent poster archives at the official Rainbow Serpent website: http:/ / www.greenant.com/ oldsite/ rainbow2000.html.

85. The Official Rainbow Serpent Homepage, 'Philosophy', www.rainbowserpent.net/ background/ philosophy (accessed 24/3/2006). 
The Rainbow Serpent Festival is an example of white Australians seeking association with the 'Other'. The 'Other' is what mystifies them, drawing them away from their weekly structural matrix towards weekend flirtations with imagined primitives. The evocative use of the Dreaming ideology coupled with decorative A boriginal iconography, a welcome-to-country ceremony and what is listed on the program as a 'spiritual blessing for inner peace with Aboriginal elder and reigning Miss Rainbow Auntie Mona Wilson' gives the vague appearance that festival attendees are engaging with A boriginal culture; but there is no evidence that any long-term or beneficial dialogue is produced in this instance. ${ }^{86}$ In fact, coming together to dance in this case exhibits limited empathy or even understanding of the issues facing A borigines, and instead represents individualistic attempts at self-fulfilment via pseudo-Aboriginal imaginings of dancing upon the earth. To support this argument, Jane Mulcock reminds us that practices of cultural borrowing and fusion of Aboriginal and European traditions are highly contentious and ethically ambiguous. The phenomenon of cultural borrowing is clearly apparent in this case and can be noticed just as easily in North American rave culture's appropriation of Shamanic mysticism in its (re)creation of the 'technosharman' ${ }^{87}$ Indigenous cultural symbols and spiritual ity have become part of a 'global cultural supermarket'. Mulcock suggests that 'in the aisles of the cultural supermarket all images and ideas have the potential to become freely available, depoliticized, resources easily available to all producers and consumers of postmodern popular culture' $^{88}$ In the case of the Rainbow Serpent Festival, the commodification of N ew Age spirituality and primitive imaginings is reflected in the escalating ticket price (directly in contrast to Earthdream, which is free). In 1999, ticket prices were $\$ 32$ presale and in 2007 they had climbed to $\$ 135$ presale - thus making dalliance with 'Otherness' only available to those who can afford the luxury.

When assessing Earthdream and the Rainbow Serpent Festival comparatively, we clearly see two different logics of dance emerging. Despite their best intentions, not all bush doofs or neo-tribal communities provide an example of ethically correct engagement with Indigenous cultures. In the case of Earthdream, dance is brought into play as a dynamic political praxis. Participants in FreeN RG culture and neo-corroborees such as Earthdream are aware of their 'unsettled settledness', their awkwardness with the state of A ustralian national identity resting on the distinctions made between the coloniser and the colonised. ${ }^{89} \mathrm{Neo}$-corroborees of this nature potentially provide an opportunity for the coming together for black and white, urban and rural A ustralians to dance on Aboriginal land and fully acknowledge the traditional ownership of the land upon which they dance. Dance in this instance, typified by Earthdream, presents an active and participatory form of engagement with Aboriginal people and provides a space - both physically (via dance) and virtually (via internet dialogue) - where protest is staged and difference is celebrated. Thus dance, in some instances, provides Australian youth with a means of performing social protest in a pleasurable manner,

86. The Official Rainbow Serpent Homepage, 'Event', http:/ / www.rainbowserpent.net/ event/ lifestyle/ (accessed 28/6/2007).

87. Hutson 1999: 53-77.

88. Mulcock 2001: 181.

89. Gelder and Jacobs 1998; St John 2005a: 323. 
hopefully encouraging more young Australians to actively engage with issues facing A boriginal people and Australian ecology.

\section{D ynamics of the dance}

The performers in and creators of Corroboree, and participants in and organisers of FreeN RG neo-corroborees were/ are und oubtedly responding to a genuine interest and respect for Aboriginal culture, and in both instances have been inspired to communicate these feelings and concerns via dance. Dance is free from the restrictions of spoken language. Its multi-sensorial and kinaesthetic powers allow for a communicative freedom that a verbal exchange of ideas cannot provide. Nevertheless, it is imperative to acknowledge that universality does not exist amongst dancers, nor does dance have any greater freedom than literal forms of communication to appropriate cultural products without regard of cultural ownership. ${ }^{90}$ The tradition of ballet suggests rigidity of performance, and the formulaic methodology of its creation insists that dominant performance aesthetics are maintained. Ballet, even in the modern stylings of Beth Dean's Corroboree, is merely ornamented or embellished by what it borrows from other cultural traditions, thus rendering it almost impossible for dance of this kind to allow genuine intercultural engagement.

FreeNRG culture is not bound by strict or limiting performance traditions, thus organisers are able to stage their performances in a multiplicity of ways that respond directly to the creative desire and political motivations of participants. While the social and political consciousness of FreeNRG culture does not guarantee ethical engagement, it does suggest that FreeNRG culture is more aware of the legacies of colonialism and, as such, more likely to achieve genuine dial ogue. For doofers, 'the dance space becomes a portal, a dreaming, a coming together on many different levels as the zone provides a point of personal and community transformation'. ${ }^{91}$ The zone created by and around the dance space is where participants action their challenge to conservative ideologies and social injustice by uniting in a celebration of difference and reconnecting with the ground under their feet. And it is the collective efforts required in creating these zones of protest that generate a space where engagement, dialogue and understanding can potentially evolve.

Yet, like Dean's Corroboree 50 years earlier, these performances - despite their best intentions - may still be interpreted by some as uneasy cultural encounters, where cultural appropriation/ sharing takes settler performers to that same uncomfortable space; a space identified by Nicholas Thomas where awe, respect, partial understanding, acknowledgment, misrecognition, hostility, exploitation and denial co-mingle ${ }^{92}$ It seems that this will be an irresolvable component of settler/ Indigenous cultural relations in settler societies like Australia in the present and in the future. If this is so, then we might well consider why it is that these conflicted states are absent from the internationally acclaimed performances by Aboriginal choreographers and dancers from the Bangarra Dance Theatre? Potentially this is because Bangarra, as Dennis Foley suggests, is not attempting to recreate culture but rather continue it. 'They are not reinventing

\footnotetext{
90. Kaeppler 2001; Stock 2001.

91. Williamson 2001: 49.

92. Thomas 1999.
} 
culture, they are continuing culture, and they are interpreting culture, and also incorporating other aspects of other cultures into their dance. ${ }^{\prime 93}$ While the same could be claimed at a superficial level for both Dean and the doof culture of Earthdream, there is one unmistakable difference: settler paternalism and appropriation are absent from Bangarra performances.

\section{References}

\section{Primary sources}

Papers of Victor Carell and Beth Dean, 1904-2001, MLMSS, New South Wales State Library, Sydney.

\section{Secondary sources}

Australian N ews and Information Bureau 1947, 'Australian Aboriginal dances', The D ancing Times, N ovember: 70.

Berg, Shelley C 1988, Le sacre du printemps: seven productions from N ijinsky to Graham, UMI Research Press, Ann Arbor, Michigan.

Bey, Hakim 1991, T.A .Z. The Temporary A utonomous Z one: ontological anarchy, poetic terrorism, Autonomedia, Brooklyn.

Black, Roman 1964, Old and new A ustralian A boriginal art, Angus \& Robertson, Sydney.

Callaway, Anita 2000, V isual ephemera: theatrical art in nineteenth-century A ustralia, University of New South Wales Press, Sydney.

Clifford, James 2003, 'Histories of the tribal and the modern - 1985' in Primitivism and twentieth-century art: a documentary history, Jack Flam and Miriam Deutsch (eds), University of California Press, Berkeley: 351-413.

Dean, Beth 1966, The many worlds of dance, Murray, Sydney.

Dean, Beth and Victor Carrel 1955, D ust for the dancers, Ure Smith, Sydney.

— 1983, Twin journey: to sing, to dance, to live, Pacific Publications, Sydney.

— 1987, Gentle genius: a life of J ohn A ntill, A kron Press, Sydney.

Deloria, Phillip J 1998, Playing Indian, Yale University Press, New Haven.

Dugan, Dennis 1968, 'Review', Sydney M orning H erald, 20 January.

Garling, Jean 1950s, A ustralian notes on the ballet; studies by D aryl Lindsay and William Constable; decorations by Eugénie Crawford, Legend Press, Sydney.

Gelder, Ken 2001, 'Foreword' in FreeN R G : notes from the edge of the dance fl oor, Graham St John (ed), Common Ground Press, Altona: xvi-xvii.

Gelder, Ken and Jane Jacobs 1998, U ncanny A ustralia: sacredness and identity in a postcolonial nation, University of Melbourne Press, Melbourne.

Gibbons, Peter 2002, 'Cultural colonization and national identity', N ew Z ealand Journal of $\mathrm{H}$ istory 36: 5-17.

Gibson, Chris 1999, 'Subversive sites: Rave culture, spatial politics and the internet in Sydney', A rea 31(1): 19-33.

Greenberg, Clement 1939, 'Avant-garde and kitsch', Partisan Review VI(5): 34-49, http:/ / www.sharecom.ca/ greenberg/ kitsch.html

93. Foley quoted in Read (in publication). 
Henry, R, F Magowan and D M urray 2000, 'Introduction', The politics of dance, a special issue of The A ustralian Journal of A nthropology 11(3): 253-60.

Hutson, Scott R 1999, 'Technoshamanism: spiritual healing in the rave subculture', Popular M usic and Society 23(3): 53-77.

Kaeppler, Adrienne L 2001, 'Dance and the concept of style', Y earbook for Traditional M usic 33: 49-63.

Kleinert, Sylvia 2006, 'A boriginal ity in the city: re-reading Koorie photographs', A boriginal $\mathrm{H}$ istory 30: 69-94.

Kleinert, Sylvia, and Margo Neal (eds) 2000, The 0 xford companion to A boriginal art and culture, Oxford University Press, Melbourne.

Langton, Marcia 1993, 'W ell I heard it on the radio and I saw it on the television': A n essay for the A ustralian Film Commission on the politics and aesthetics of filmmaking by and about A boriginal people and things, A ustralian Film Commission, Sydney.

— 1996, 'What do we mean by wilderness? Wilderness and terra nullius in A ustralian art', The Sydney Papers 8(1): 21.

Lattas, A ndrew 1989, 'Colonising the Other: dreaming, A boriginal painting and white man's search for a soul', O live P ink Society Bulletin 1/ 2: 24.

Le Brun Holmes, Sandra 1999, Faces in the sun: outback journey, Penguin, Ringwood.

Luckman, Susan 2003, 'Going bush and finding one's tribe: raving escape and the bush doof', Continuum: Journal of M edia and Cultural Studies 17(3): 315-330.

Magowan, Fiona and Karl Neuenfeldt (eds) 2005, Landscapes of Indigenous performance: music, song and dance of the Torres Strait and A rnhem Land, A boriginal Studies Press, Canberra.

McEvilley, Thomas 1996, 'Doctor, lawyer, Indian chief: "Primitivism” in twentiethcentury art at the Museum of Modern Art' in Capacity: history, the world, and the self in contemporary art and criticism, Overseas Publishers Association, Amsterdam: 101-118.

Mulcock, Jane 2001, 'Creativity and politics in the cultural supermarket', Continuum: Journal of M edia and Cultural Studies 15(2): 169-185.

Mundine, Djon 2003, 'A dance through the desert' in D ancing up country: the art of D orothy N apangardi, Museum of Contemporary Art, Sydney: 68-71.

North, Michael 1994, The dialect of modernism: race, language, and twentieth century literature, Oxford University Press, Oxford.

Parsons, Michael 2002, “'A h that I could convey a proper idea of this interesting wild play of the natives": corroborees and the rise of Indigenous Australian cultural tourism', A ustralian A boriginal Studies 2: 14-26.

Potter, Michelle 2004, 'Corroboree', N ational Library of A ustralia N ews, XIV(6): 1, http:/ / www.nla.gov.au/ pub/ nlanews/ 2004/ mar04/ article3.html

Read, Peter (in publication), 'Whose landscape? Who's exiled?' in Landscapes of Exile, Anna Haebich and Baden Offord (eds), Peter Lang, Oxford.

Rubin, William 1984, 'Modernist primitivism: an introduction' in Primitivism in 20th century art: affinity of the tribal and the modern, William Rubin (ed), Museum of Modern Art, New York: 1-84. 
Scruton, Roger 1999, 'Kitsch and the modern predicament', City Journal, Winter: np, http:/ / www.city-journal.org/ html/ 9_1_urbanities_kitsch_and_the.html

St John, Graham 2001a, 'Doof! A ustralian post-rave culture' in FreeN RG: notes from the edge of the dance fl oor, Graham St John (ed), Common Ground Press, Altona: 9-36.

— 2001b, 'Techno terra-ism: feral systems and sound futures' in F reeN R G : notes from the edge of the dance fl oor, Graham St John (ed), Common Ground Press, Altona: 109-130.

- (ed) 2001c, FreN R G : notes from the edge of the dance floor, Common Ground Press, Altona.

— 2005a, 'Outback vibes: sound systems on the road to legitimacy', P ostcolonial Studies 8: 321-336.

— 2005b, 'Off road show: techno, protest and feral theatre', C ontinuum: Journal of M edia and Cultural Studies 19(1): 5-20.

Stock, Cheryl 2001, 'Myth of a universal dance language: tensions between globalisation and cultural difference', A sia Pacific D ance Bridge: A cademic Conference, World Dance Alliance, Singapore: 246-62.

Strong, Peter 2001, 'Doofstory: Sydney Park to the desert' in FreeN R G : notes from the edge of the dance floor, Graham St John (ed), Common Ground Press, Altona: 71-90.

Thomas, Nicholas 1999, P ossessions: Indigenous art/colonial culture, Thames and Hudson, London.

Torgovnick, Marianna 1990, G one primitive: savage intellects, modern lives, Chicago University Press, Chicago.

— 1996, Primitive passions: men, women, and the quest for ecstasy, University of Chicago Press, Chicago.

Tramacchi, Des 2000, 'Field tripping: psychedelic communities and ritual in the Australian bush', Journal of Contemporary Religion 15(2): 201-213.

Van de Van, A nne-Marie 2004, 'Speaking out: introduction to Indigenous A ustralian graphic design, 1930s to now', paper presented at DDD (graphic) Gallery, Osaka, 25 N ovember.

Vignando, Catrina 2000, 'Corroboree: A boriginal inspiration in contemporary A ustralian ballet' in Picturing the 'primitif': images of race in daily life, Julie Marcus (ed), LHR Press, Canada Bay, New South Wales: 211-222.

Williamson, Kathleen 1999, 'Trance magick', http:/ / www.hofmann.org/ voices/ aussie.html (accessed 14/ 4/ 2006).

- 2001, 'Propagating abominable knowledge' in Free N R G: N otes from the edge of the dance floor, Graham St John (ed), Common Ground Press, Altona: 37-56.

Willis, A nne-Marie 1993, Illusions of identity: The art of nation, Hale \& Iremonger, Sydney. 